\title{
Changing the Overall Shape of Heterodinuclear Helicates via Substitution of Acylhydrazones by Tosylhydrazones
}

\author{
Markus Albrecht ${ }^{\mathrm{a}}$, Irene Latorre ${ }^{\mathrm{a}}$, Yufeng $\mathrm{Liu}^{\mathrm{a}}$, and Roland Fröhlich ${ }^{\mathrm{b}}$ \\ ${ }^{a}$ Institut für Organische Chemie, RWTH Aachen University, Landoltweg 1, 52074 Aachen, Germany \\ b Organisch-chemisches Institut, Universität Münster, Corrensstraße 40, 48149 Münster, Germany \\ Reprint requests to Prof. Markus Albrecht. E-mail: markus.albrecht@oc.rwth-aachen.de
}

Z. Naturforsch. 2010, 65b, 311-316; received November 11, 2009

Dedicated to Professor Rolf W. Saalfrank on the occasion of his $70^{\text {th }}$ birthday, on recognition of his outstanding contributions to the field of metallosupramolecular chemistry

\begin{abstract}
Heterodinuclear helicate-type complexes are formed from acyl and tosyl hydrazone-substituted catechol ligands. Due to the different geometry of the carboxylate compared to the sulfonate unit, different overall structures are observed for the complexes. The acylate results in the formation of a cylindrical triple-stranded system, while in the tosylate the pendant substituents fold back and form a more condensed structure.
\end{abstract}

Key words: Self-assembly, Helicates, Heteronuclear, Catechol, Hydrazone

\section{Introduction}

Metallosupramolecular chemistry opens up an easy entry to a family of complicated supramolecular architectures by simple self-assembly processes. Welldefined structures can be formed which possess special structural features as well as properties [1]. In order to introduce functionality, the concept can be used to build up heteronuclear coordination compounds with the ability for metal-metal communication. However, this requires that different metals are bound selectively at well defined positions [2].

A well investigated class of metallosupramolecular complexes are the helicates [3-6]. They are defined as coordination compounds in which two or more linear ligand strands are wrapped around two or more metal atoms to form a double- or triple-stranded helix [7]. A special challenge is to design ligands capable of forming sequential coordination compounds with different metal ions located in distinct positions by connecting two different ligands that are suited to coordinate different metals [8].

This concept was used by Piguet and Bünzli [9] for the formation of $d-f$ heterodinuclear complexes (ligand 1) [10] and by us for the formation of a gallium(III)titanium(IV) complex (with ligand 2) [11]. Recently, Hahn introduced the sequential catechol - benzenedithiol ligand 3 [12]. All the ligands $\mathbf{1}-\mathbf{3}$ have the disadvantage that their preparation is cumbersome,
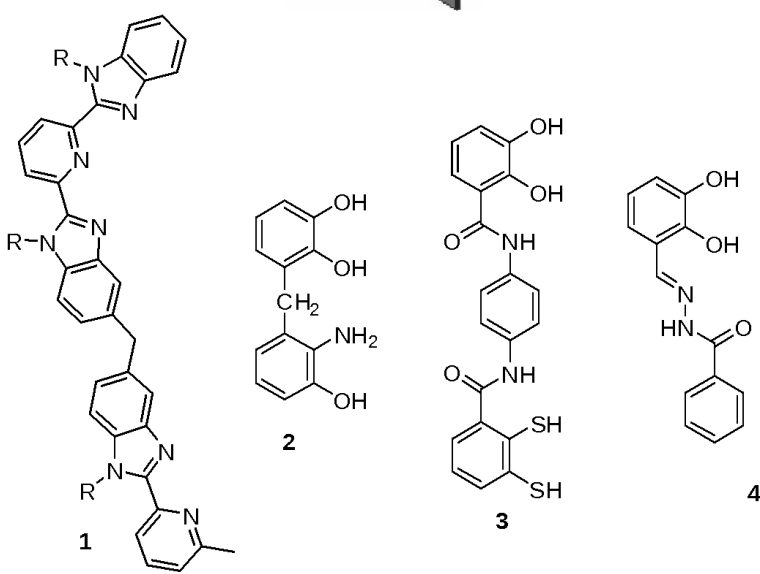

Fig. 1 .

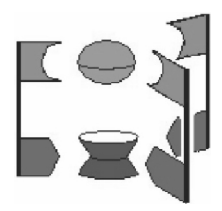

and that they are only available by multistep synthetic procedures $[13,14]$. Therefore we introduced the catechol-acylhydrazone 4 (Fig. 1), which is easily available in large amounts and forms heterodinuclear helicates with gallium(III) and lanthanum(III), for example [15].

Based on these earlier results we now present the substitution of the benzoylhydrazone of $\mathbf{4}$ by tosylhy- 
drazone to obtain the new ligand $\mathbf{5}$. This changes the overall structural features of heterodinuclear coordination compounds, introducing a new arrangement of the pendant aromatic substitutents relative to the heterodinuclear complex moiety.

\section{Results and Discussion}

\section{The catechol-hydrazone ligands $\mathbf{4}$ and $\mathbf{5}$}

The straightforward preparation of ligand $\mathbf{4}$ has already been described. Simple condensation of 2,3dihydroxybenzaldehyde with benzoylhydrazone affords the ligand in high purity and very good yields [15]. By analogy, the tosylhydrazone 5 was prepared by reaction of 2,3-dihydroxybenzaldehyde with tosyl hydrazine. The desired ligand $\mathbf{5}$ was obtained in $81 \%$ yield after recrystallization from methanol/ ether (Scheme 1).

The tosylhydrazone 5 was characterized by ${ }^{1} \mathrm{H}$ NMR spectroscopy in $\left[\mathrm{D}_{4}\right]$ methanol showing a singlet resonance for the $\mathrm{CH}=\mathrm{N}$ proton at $\delta=7.96$ and two doublets at $\delta=7.79$ and 7.39 with $J=8.7 \mathrm{~Hz}$ for the aromatic tosyl protons. The catechol hydrogen atoms lead to two resonances at $\delta=6.82(1 \mathrm{H})$ and $6.72(2 \mathrm{H})$. Finally, the methyl group is observed as a singlet at $\delta=2.39$. Mass spectra and elemental analyses are also consistent with the constitution of compound $\mathbf{5}$.

Crystals suitable for X-ray diffraction experiments were obtained for the ligand 4 . The structure shows the conformation of 4 (Fig. 2) in the solid state. A close to planar arrangement of the catechol, hydrazone and phenyl groups is observed.

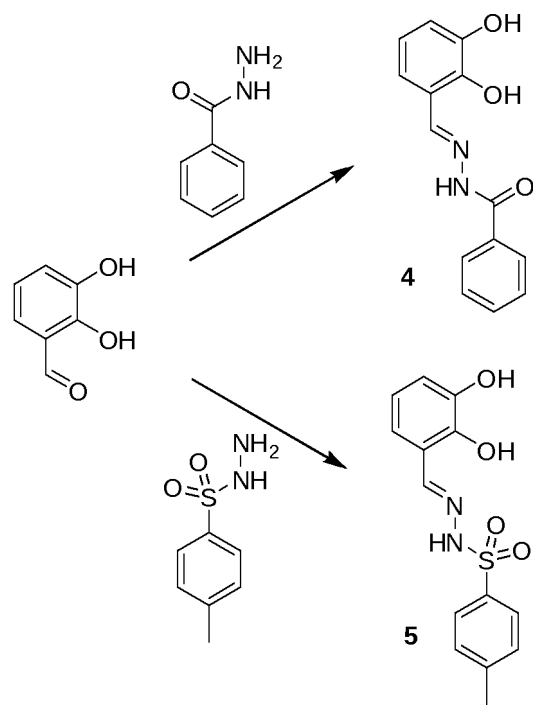

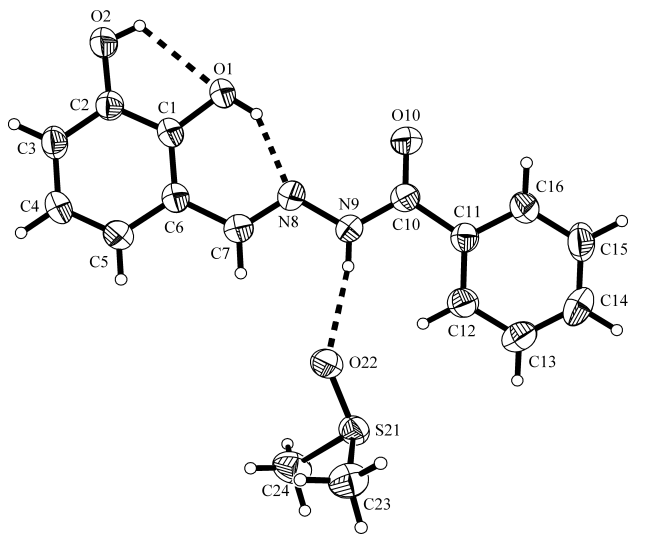

Fig. 2. Molecular structure of ligand $4 \cdot$ DMSO in the solid state. The displacement ellipsoids are drawn at the $50 \%$ probability level.

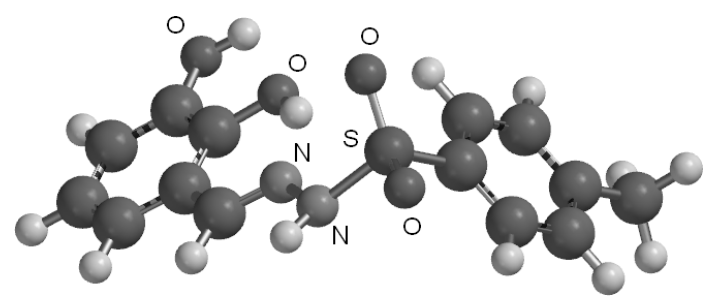

Fig. 3. Molecular structure of $\mathbf{5}$ as calculated by force field methods (SPARTAN O8).

An interesting intramolecular hydrogen bonding pattern is observed in the crystal structure of 4 . The hydroxyl group in 2-position of the catechol binds to the hydrazone $=\mathrm{N}$ - atom, and the $\mathrm{OH}$ group in 1-position is binding to the $\mathrm{O}$ atom in 2-position [16]. The carbonyl oxygen atom of the acyl unit is oriented to the "front" of the molecule forming the overall tridentate site for metal coordination. In addition, one molecule of DMSO cocrystallizes and becomes attached to the hydrazone hydrogen atom of $\mathbf{4}$ by intermolecular hydrogen bonding.

We were not able to obtain crystals of 5 suitable for X-ray diffraction. However, simple modeling using the force field routine of SPARTAN O8 [17] reveals the major difference between the ligands $\mathbf{4}$ and 5 (see Fig. 3) associated with the different geometries at the $\mathrm{SO}_{2}$ unit of $\mathbf{5}$ compared to the $\mathrm{CO}$ unit of $\mathbf{4}$. While the latter is planar, the sulfur atom in $\mathbf{5}$ adopts a tetrahedral coordination geometry introducing a "kink" in the ligand and leading to a non-planar structure. However, the tridentate $\mathbf{O} 2_{\text {catechol }}-\mathrm{C}=\mathbf{N}$ $\mathrm{S}=\mathbf{O}$ pattern for the coordination of metal ions is still Scheme 1. intact. 
Coordination studies and comparison of the structural features of complexes of ligands $\mathbf{4}$ and $\mathbf{5}$

A thorough coordination study of the ligand $\mathbf{4}$ and its bromo-substituted derivative has already been published [15]. We now report the preparation of the aluminum(III)/lanthanum(III) complex 6, which was crystallized from DMF/methanol, and its molecular structure in the crystalline state.

With ligand 5 we tried to prepare the neutral titanium(IV)/calcium(II) complex $\mathbf{7 b}$ and the cationic titanium(IV)/lanthanum(III) complex 7c. Both coordination compounds showed the expected NMR spectra, and their ions were observed by ESI MS (7b: MS ((+)-ESI): $m / z=1038.91\left\{\mathrm{~L}_{3} \mathrm{TiCa}+\mathrm{K}\right\}^{+}$, MS ((-)-ESI): $m / z=999.25\left\{\mathrm{~L}_{3} \mathrm{TiCa}-\mathrm{H}\right\}^{-} ; \mathbf{7 c}: \mathrm{MS}$ $((+)-\mathrm{ESI}): m / z=2236.63\left\{\left[\mathrm{~L}_{3} \mathrm{LaTi}\right]_{2} \mathrm{~K}\right\}^{+}$and 1123.50 $\left.\left\{\mathrm{L}_{3} \mathrm{LaTiNaH}\right\}^{+}\right)$. However, no correct elemental analysis was obtained for those complexes. Finally we succeeded to obtain the anionic heterodinuclear titanium(IV)/potassium complex 7a, which could be fully characterized. We were also able to obtain crystals of 7a from methanol and could determine the crystal structure by X-ray diffraction (Figs. 4 and 5).

Fig. 5 shows the results of the crystallographic structure analyses of $\mathbf{6}$ and $7 \mathbf{a}$ (only the triple-stranded helicate parts are shown). Fig. 5a reveals that the deprotonated ligand $\mathbf{4}$ adopts a very similar conformation in the complex $\mathbf{6}$ as was observed in the solid-state structure of the free ligand. Three of the ligands are wrapped around the two metal atoms in a helical fashion with aluminum binding to the three catechol units giving it a coordination number of six. Lanthanum(III) is coordinated to ten donor atoms with three tridentate $\mathbf{O} 2_{\text {catechol }}-\mathbf{C}=\mathbf{N}-\mathrm{S}=\mathbf{O}$ units of the ligands and one DMF. Fig. 5b exhibits a view down the aluminumlanthanum axis revealing the helical arrangement of the ligands.

The related heteronuclear coordination compound $7 \mathbf{a}$ adopts a very different, more compact structure. The coordination pattern again shows the helical wrapping around the metal ions. However, the tetrahedral coordination geometry around the sulfur atom introduces a break in the helical arrangement leading to a folding back of the tosyl groups into the three grooves of the triple helical complex moiety. This is nicely seen from Fig. 5c (side view) and 5d (view down the Ti-K axis).

Bond lengths between metal atoms and ligands are shorter in the aluminum/lanthanum (6) as compared to the titanium/potassium complex (7a). The Al-O
6

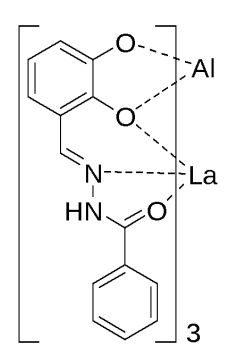

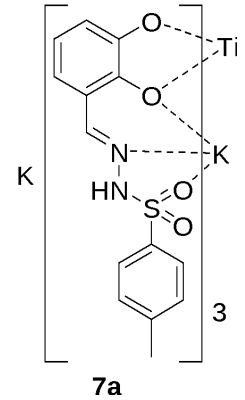

$7 a$
Fig. 4. The heterodinuclear helicates 6 and $7 \mathbf{a}$.

bonds to catecholate oxygen atoms are in the ranges $1.866(5)-1.881(5)$ (oxygen atom in 3-position) and $1.936(4)-1.956(5) \AA$ (oxygen atom in 2-position), while corresponding titanium-oxygen separations of $1.949-19.960(5)(\mathrm{O} 3)$ and $1.954-1.975(5) \AA(\mathrm{O} 2)$ are found. Hereby the bridging oxygen atoms in 2position show longer bonds due to their lower donor character. The more highly coordinated metal atom shows its longest bond to the central nitrogen atom of the tridentate coordinating unit with the distances $2.742-2.918(6) \AA$ for 6 and 3.065-3.191(5) $\AA$ for 7a. Metal-to-oxygen distances are in the same range for the catecholate and the acylate or tosylate oxygen atoms with shorter bonds observed in $6(\mathrm{La}-\mathrm{O}=$ $2.476-2.658(4) \AA)$ in comparison to $7 \mathbf{a}(\mathrm{K}-\mathrm{O}=$ $2.737-2.799(4) \AA)$.

Comparison of the two structures ( 6 and 7a) reveals a very different overall geometry of the complexes. The acyl hydrazones are planar leading to a linear arrangement of the ligands and a cylinder-type structure of the dinuclear compound. In the tosyl hydrazones the folding of the ligand results in a more spherical shape of the complex. This shows that simple substitution of one connecting unit in the ligand results in differently shaped metallosupramolecular objects.

\section{Conclusion}

We have presented two ligands $\mathbf{4}$ and $\mathbf{5}$, each having one tridentate as well as one bidentate coordination site for metal ions. Therefore they are ideal for the self-assembly of heterodinuclear helicates $(6,7 \mathbf{a})$ incorporating either $f$ - or heavy $s$-block cations. The two ligands differ in the tridentate coordination site, with a carbonyl versus a sulfonyl unit. Both are able to bind to the metal cations, but result in coordination compounds with very different overall shapes. This is of course important for the development of structurally different functional derivatives based on the hetero- 


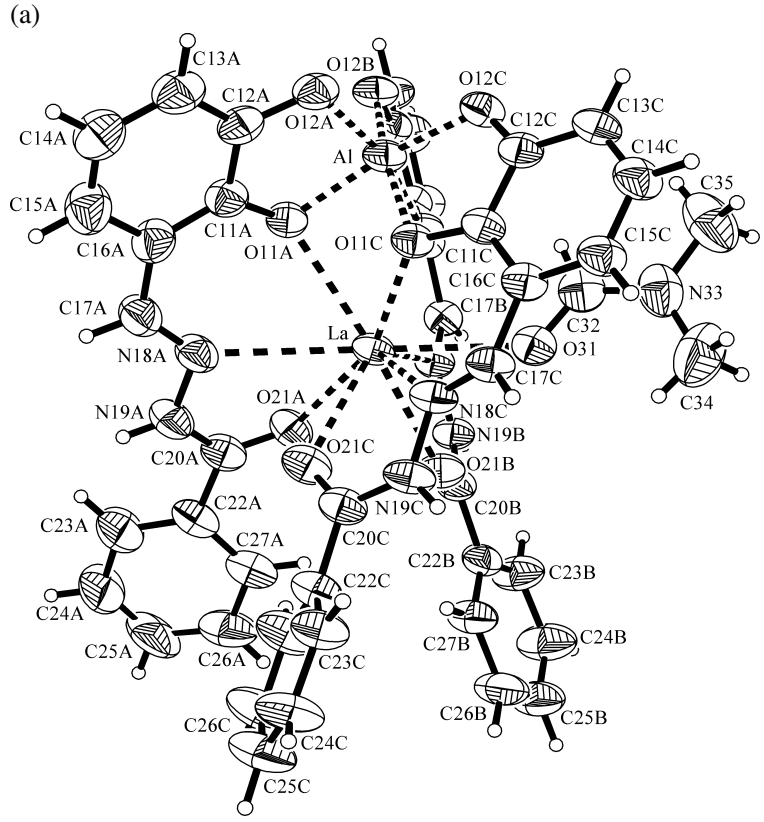

(b)

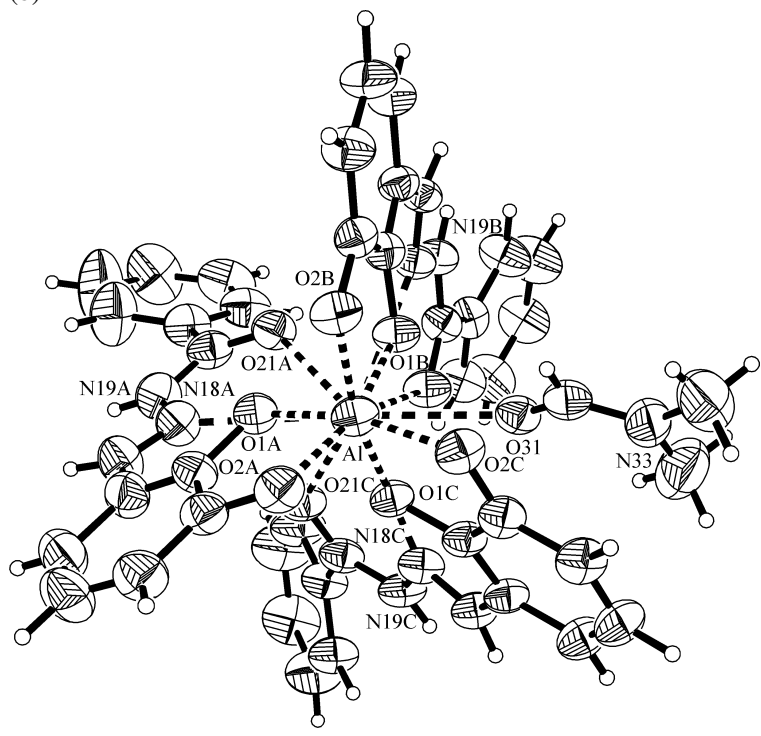

dinuclear helicate core and differently arranged substituents in side chains.

\section{Experimental Section}

Commercially available reagents were used as received. The solvents were distilled and used without further purification. NMR spectra were taken on Varian Mercury 300 or Inova 400, mass spectrometric data on Finnigan SSQ 7000 and Thermo Deca XP instruments as EI (70 eV) or ESI. The infrared spectra were obtained on a PerkinElmer Spektrum (c)

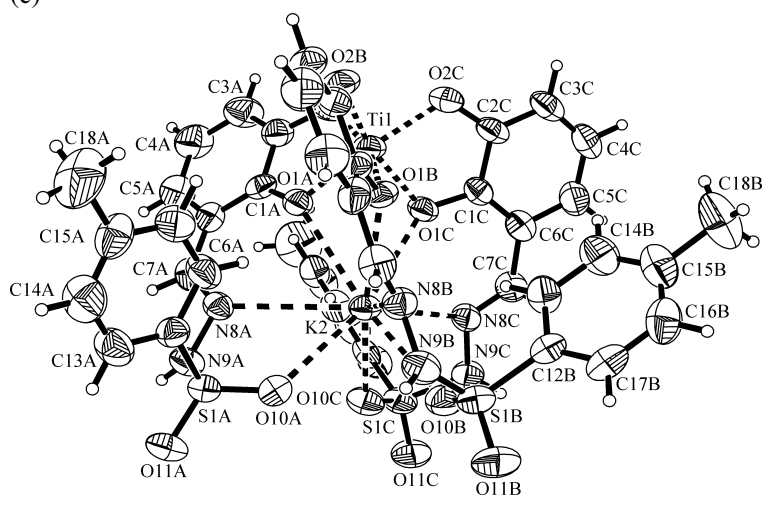

(d)

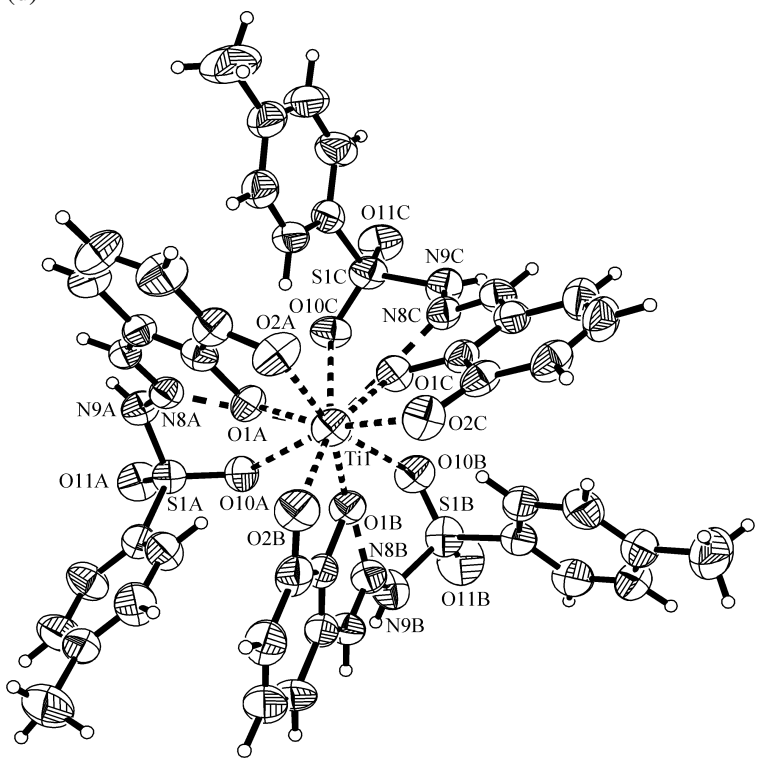

Fig. 5. Molecular structures of the heterodinuclear helicates $\mathbf{6}(\mathrm{a}, \mathrm{b})$ and $7 \mathbf{a}(\mathrm{c}, \mathrm{d})$. The displacement ellipsoids are drawn at the $50 \%$ probability level.

100 FTIR spectrometer and were measured in $\mathrm{KBr}(4000-$ $650 \mathrm{~cm}^{-1}$ ) or neat. Elemental analyses were measured on a CHN-O-Rapid Vario EL from Heraeus, melting points on a Büchi B-540 melting point device.

Data sets were collected on a Nonius KappaCCD diffractometer with Mo radiation and equipped with a rotating anode generator. Programs used: data collection COLLECT [18], data reduction DENZO-SMN [19], absorption correction SortaV [20,21] and DENZo [22], structure solution SHELXS-97 [23], structure refinement SHELXL-97 [24]. 
CCDC 755077-755079 contain the supplementary crystallographic data for this paper. These data can be obtained free of charge via www.ccdc.cam.ac.uk/data_request/cif.

\section{Ligand 4}

For the preparation and characterization of $\mathbf{4}$, see reference [15].

$\mathrm{X}$-Ray crystal structure analysis of 4: formula $\mathrm{C}_{16} \mathrm{H}_{18} \mathrm{~N}_{2} \mathrm{O}_{4} \mathrm{~S}, M_{\mathrm{r}}=334.38$, light-yellow crystal, $0.20 \times$ $0.20 \times 0.05 \mathrm{~mm}^{3}$, monoclinic, space group $P 2_{1} / c$ (no. 14), $a=10.9719(5), b=15.3749(7), c=9.9061(4) \AA, \beta=$ 96.670(2) $)^{\circ}, V=1659.77(13) \AA^{3}, Z=4, \rho_{\text {calc }}=1.34 \mathrm{~g}$ $\mathrm{cm}^{-3}, \mu=1.9 \mathrm{~mm}^{-1}$, empirical absorption correction $(0.700 \leq \mathrm{T} \leq 0.910), \lambda=1.54178 \AA, T=223(2) \mathrm{K}, \omega$ and $\varphi$ scans, 12608 reflections collected $( \pm h, \pm k, \pm l)$, $[(\sin \theta) / \lambda]=0.60 \AA^{-1}, 2947$ independent $\left(R_{\text {int }}=0.047\right)$ and 2590 observed reflections $[I \geq 2 \sigma(I)], 215$ refined parameters, $R=0.041, w R^{2}=0.114$, max. $/ \mathrm{min}$. residual electron density $0.26 /-0.28$ e $\AA^{-3}$. Comment: Hydrogen atoms at $\mathrm{N} 9$ from difference fourier map, others calculated and refined as riding atoms.

\section{Ligand 5}

To a stirred solution of 4-methylbenzenesulfonylhydrazine (372.46 mg, $2 \mathrm{mmol}, 2$ equiv.) in $\mathrm{MeOH}(20 \mathrm{~mL})$ at r.t. a solution of 2,3-dihydroxy-benzaldehyde $(276 \mathrm{mg}$, $2 \mathrm{mmol}, 2$ equiv. $)$ in $\mathrm{MeOH}(20 \mathrm{~mL})$ was added dropwise within $4 \mathrm{~min}$. The mixture was stirred for $72 \mathrm{~h}$ at r.t.. The solvent was removed by rotary evaporation, and the product was recrystallized twice from $\mathrm{MeOH}: \mathrm{Et}_{2} \mathrm{O}(1: 2)$. Ligand 5 was obtained as a dark-grey solid (495 mg, $1.62 \mathrm{mmol}, 81 \%$ yield). M. p.: $187.3{ }^{\circ} \mathrm{C} .-{ }^{1} \mathrm{H}$ NMR $\left(400 \mathrm{MHz}, \mathrm{CD}_{3} \mathrm{OD}\right): \delta=$ $7.96(\mathrm{~s}, 1 \mathrm{H}, \mathrm{CH}=\mathrm{N}), 7.79\left(\mathrm{~d}, J=8.7 \mathrm{~Hz}, 2 \mathrm{H}, \mathrm{CH}_{\mathrm{Tol}}\right), 7.39(\mathrm{~d}$, $\left.J=8.7 \mathrm{~Hz}, 2 \mathrm{H}, \mathrm{CH}_{\mathrm{Tol}}\right), 6.82(\mathrm{dd}, J=7.2 \mathrm{~Hz}, J=2.5 \mathrm{~Hz}, 1 \mathrm{H}$, $\left.\mathrm{CH}_{\mathrm{Cat}}\right), 6.72\left(\mathrm{~m}, 2 \mathrm{H}, \mathrm{CH}_{\mathrm{Cat}}\right), 2.39\left(\mathrm{~s}, 3 \mathrm{H}, \mathrm{CH}_{3}\right)$. - IR (neat): $v=3485,3218,1615,1593,1475,1367,1318,1281,1200$, $1159,1062,925,816,724,663 \mathrm{~cm}^{-1}$. - MS (EI): $\mathrm{m} / z(\%)=$ 306.1 (100) $[\mathrm{M}]^{+}$. $-\mathrm{C}_{14} \mathrm{H}_{14} \mathrm{~N}_{2} \mathrm{O}_{4} \mathrm{~S}$ : calcd. C 54.89, H 4.61, $\mathrm{N} 9.14$; found C $55.06 \mathrm{H} 4.23 \mathrm{~N} 9.04$.

\section{Complex 6}

$100 \mathrm{mg}$ of 4 (0.39 mmol, 3 equiv. $), 48.4 \mathrm{mg}$ of $\mathrm{LaCl}_{3} \cdot 7 \mathrm{H}_{2} \mathrm{O}$ (0.13 mmol, 1 equiv.), $17.4 \mathrm{mg}$ of $\mathrm{AlCl}_{3}$ (0.13 mmol, 1 equiv.), and $54 \mathrm{mg}$ of $\mathrm{K}_{2} \mathrm{CO}_{3}(0.39 \mathrm{mmol}$, 3 equiv.) were combined in a flask and dissolved in $10 \mathrm{~mL}$ of $\mathrm{MeOH}$. The reaction mixture was heated to reflux for $5 \mathrm{~min}$ and then stirred at r.t. for $3 \mathrm{~d}$. A yellow solid formed, which was filtered off and washed with $\mathrm{Et}_{2} \mathrm{O}$. The product was obtained as a yellow solid in $75 \%$ yield $(90 \mathrm{mg}$, $0.096 \mathrm{mmol}) .-{ }^{1} \mathrm{H}$ NMR (400 MHz, [D 6 ]DMSO): $\delta=$ $8.52(\mathrm{~s}, 3 \mathrm{H}, \mathrm{CH}=\mathrm{N}), 7.77\left(\mathrm{~d}, J=7.6 \mathrm{~Hz}, 6 \mathrm{H}, \mathrm{CH}_{\mathrm{Ph}}\right)$, $7.54\left(\mathrm{t}, J=7.6 \mathrm{~Hz}, 3 \mathrm{H}, \mathrm{CH}_{\mathrm{Ph}}\right), 7.24(\mathrm{t}, J=7.6 \mathrm{~Hz}, 6 \mathrm{H}$, $\left.\mathrm{CH}_{\mathrm{Ph}}\right), 6.37$ (m, 9H, $\left.\mathrm{CH}_{\mathrm{Cat}}\right)$. - IR (neat): $v=3190,3058$,
2846, 2112, 1601, 1559, 1456, 1376, 1255, 1216, 1049, 903, 869, 759, 739, 697, $657 \mathrm{~cm}^{-1}$. - MS ((-)-ESI): $\mathrm{m} / \mathrm{z}=$ $535.87\left[\mathrm{~L}_{2} \mathrm{Al}\right]^{-}, 927.47\left[\mathrm{~L}_{3} \mathrm{LaAl}-\mathrm{H}\right]^{-}$. - MS ((+)-ESI): $m / z=929.33\left[\mathrm{~L}_{3} \mathrm{LaAlH}\right]^{+} .-\mathrm{C}_{42} \mathrm{H}_{30} \mathrm{AlLaN}_{6} \mathrm{O}_{9} \cdot 2 \mathrm{H}_{2} \mathrm{O}$ : calcd. C 52.29, H 3.55, N 8.71; found C 51.85, H 3.46, N 8.62 .

$X$-Ray crystal structure analysis of $\mathbf{6}$ : formula $\left(\mathrm{C}_{14} \mathrm{H}_{10} \mathrm{~N}_{2} \mathrm{O}_{3}\right)_{3} \mathrm{AlLa} \cdot 3 \mathrm{C}_{3} \mathrm{H}_{7} \mathrm{NO} \cdot \mathrm{CH}_{3} \mathrm{OH}, M_{\mathrm{r}}=1179.94$, yellow crystal, $0.20 \times 0.15 \times 0.10 \mathrm{~mm}^{3}$, trigonal, space group $R \overline{3}$ (no. 148), $a=41.1648(4), c=21.8016(3) \AA, V=$ 31994.2(6) $\AA^{3}, Z=18, \rho_{\text {calc }}=1.10 \mathrm{~g} \mathrm{~cm}^{-3}, \mu=0.7 \mathrm{~mm}^{-1}$, empirical absorption correction $(0.878 \leq \mathrm{T} \leq 0.936), \lambda=$ $0.71073 \AA, T=223(2) \mathrm{K}, \omega$ and $\varphi$ scans, 63578 reflections collected $( \pm h, \pm k, \pm l),[(\sin \theta) / \lambda]=0.62 \AA^{-1}, 14407$ independent $\left(R_{\text {int }}=0.076\right)$ and 9647 observed reflections $[I \geq$ $2 \sigma(I)], 645$ refined parameters, $R=0.071, w R^{2}=0.243$, max. / min. residual electron density $1.83 /-0.83$ e $\AA^{-3}$.

Comment: Hydrogen atoms calculated and refined as riding atoms; solvent molecules refined with geometrical (SAME) restraints and one common isotropic thermal parameter. The structure contains voids but the contents could not be determined in a chemically meaningful way. The use of the SQUEEZE routine in PLATON did not improve the refinement.

\section{Complex $7 a$}

To a flask charged with a solution of $83 \mathrm{mg}$ of $\mathbf{5}$ ( $0.27 \mathrm{mmol}, 3$ equiv.) in $10 \mathrm{~mL}$ of $\mathrm{MeOH}$, a solution of $23.7 \mathrm{mg}$ of $\mathrm{TiO}(\mathrm{acac})_{2}(0.09 \mathrm{mmol}, 1$ equiv. $)$ and $12.5 \mathrm{mg}$ of $\mathrm{K}_{2} \mathrm{CO}_{3}$ (0.09 mmol, 1 equiv.) was added. The mixture was stirred for $72 \mathrm{~h}$, then the solvent was removed under reduced pressure. The product was obtained as a dark-red solid in quantitative yield $(100 \mathrm{mg}, 0.09 \mathrm{mmol}) .-{ }^{1} \mathrm{H}$ NMR (400 MHz, [D 6 ]DMSO): $\delta=7.61(\mathrm{~s}, 3 \mathrm{H}, \mathrm{CH}=\mathrm{N})$, $7.64(\mathrm{~m}, 12 \mathrm{H}, \mathrm{CH}), 6.65(\mathrm{~d}, J=7.9,6 \mathrm{H}, \mathrm{CH}), 6.47(\mathrm{~m}$, $6 \mathrm{H}, \mathrm{CH}), 2.12\left(\mathrm{~s}, 9 \mathrm{H}, \mathrm{CH}_{3}\right)$. - IR (neat): $v=3539,3191$, 3051, 2109, 1595, 1441, 1322, 1248, 1160, 1017, 921, 812, 737, $666 \mathrm{~cm}^{-1}$. - MS ((+)-ESI): $\left.\mathrm{m} / z, \%\right)=1038.93(100)$ $\left[\mathrm{L}_{3} \mathrm{TiK}_{2} \mathrm{H}\right]^{+}$. - MS ((-)-ESI): $\mathrm{m} / z=999.00\left[\mathrm{~L}_{3} \mathrm{TiK}^{-}{ }^{-}\right.$. $\mathrm{C}_{42} \mathrm{H}_{36} \mathrm{~K}_{2} \mathrm{~N}_{6} \mathrm{O}_{12} \mathrm{~S}_{3} \mathrm{Ti} \cdot \mathrm{H}_{2} \mathrm{O}$ : calcd. C 47.72, H 3.62, N 7.95; found C 47.91, H 4.19, N 7.83.

$X$-Ray crystal structure analysis of 7a: formula $\left(\mathrm{C}_{14} \mathrm{H}_{12} \mathrm{~N}_{2} \mathrm{O}_{4} \mathrm{~S}\right)_{3} \mathrm{~K}_{2} \mathrm{Ti} \cdot 5 \quad \mathrm{CH}_{3} \mathrm{OH} \cdot \mathrm{H}_{2} \mathrm{O}, M_{\mathrm{r}}=1217.27$, orange crystal, $0.25 \times 0.20 \times 0.10 \mathrm{~mm}^{3}$, orthorhombic, space group Pna2 1 (no. 33), $a=26.0880(5), b=11.7108(2)$, $c=18.8757(3) \AA, V=5766.7(2) \AA^{3}, Z=4, \rho_{\text {calc }}=1.40 \mathrm{~g}$ $\mathrm{cm}^{-3}, \mu=0.5 \mathrm{~mm}^{-1}$, empirical absorption correction $(0.891 \leq \mathrm{T} \leq 0.954), \lambda=0.71073 \AA, T=223(2) \mathrm{K}, \omega$ and $\varphi$ scans, 26540 reflections collected $( \pm h, \pm k, \pm l),[(\sin \theta) / \lambda]=$ $0.66 \AA^{-1}, 13753$ independent $\left(R_{\text {int }}=0.053\right)$ and 10449 observed reflections $[I \geq 2 \sigma(I)], 701$ refined parameters, $R=0.084, w R^{2}=0.192$, Flack parameter $x=0.52(5)$, max. / min. residual electron density $0.84 /-0.44 \mathrm{e}^{-3}$. 
Comment: Structure refined as racemic twin. Hydrogen atoms calculated and refined as riding atoms; solvent molecules refined with thermal restraints (ISOR). Hydrogen atoms at the water molecule could not be located.

\section{Complex $7 \boldsymbol{b}$}

To a flask charged with a solution of $92 \mathrm{mg}$ of $\mathbf{5}$ ( $0.3 \mathrm{mmol}, 3$ equiv.) in $5 \mathrm{~mL}$ of $\mathrm{MeOH}$, a solution of $16 \mathrm{mg}$ of $\mathrm{CaAc}_{2}(0.1 \mathrm{mmol}, 1$ equiv. $)$ in $\mathrm{MeOH}$ as well as a solution of $26 \mathrm{mg}$ of $\mathrm{TiO}(\mathrm{acac})_{2}(0.1 \mathrm{mmol}, 1$ equiv. $)$ and a solution of $40 \mathrm{mg}$ of $\mathrm{K}_{2} \mathrm{CO}_{3}(0.3 \mathrm{mmol}, 3$ equiv. $)$ were added. The mixture was stirred for $72 \mathrm{~h}$. The excess of $\mathrm{K}_{2} \mathrm{CO}_{3}$ was filtered off, and the solvent was evaporated under reduced pressure. The product was obtained as a light-brown solid $(82 \mathrm{mg}$, 0.08 mmol, $82 \%$ yield). $-{ }^{1} \mathrm{H}$ NMR (400 MHz, $\mathrm{CD}_{3} \mathrm{OD}$ ): $\delta=7.94(\mathrm{~s}, 3 \mathrm{H}, \mathrm{CH}=\mathrm{N}), 7.33\left(\mathrm{~d}, J=7.7 \mathrm{~Hz}, 6 \mathrm{H}, \mathrm{CH}_{\mathrm{Tol}}\right)$, $7.10\left(\mathrm{~d}, J=7.7 \mathrm{~Hz}, 6 \mathrm{H}, \mathrm{CH}_{\mathrm{Tol}}\right), 6.52(\mathrm{~d}, J=7.5 \mathrm{~Hz}, 3 \mathrm{H}$, $\left.\mathrm{CH}_{\mathrm{Cat}}\right), 6.22\left(\mathrm{t}, J=7.5 \mathrm{~Hz}, 3 \mathrm{H}, \mathrm{CH}_{\mathrm{Cat}}\right), 5.97(\mathrm{~d}, J=7.5 \mathrm{~Hz}$, $\left.3 \mathrm{H}, \mathrm{CH}_{\mathrm{Cat}}\right), 2.30\left(\mathrm{~s}, 9 \mathrm{H}, \mathrm{CH}_{3}\right)$. - IR (neat): $v=3377,3191$, 3053, 2321, 299, 1552, 1441, 1319, 1248, 1160, 1016, 737, $666 \mathrm{~cm}^{-1}$. - MS ((-)-ESI): $\mathrm{m} / z=999.25\left[\mathrm{~L}_{3} \mathrm{TiCa}-\mathrm{H}\right]^{-} .-$ MS ((+)-ESI): $m / z=1038.91\left[\mathrm{~L}_{3} \mathrm{TiCaK}^{+}\right.$.

\section{Complex $7 c$}

To a flask charged with a solution of $92 \mathrm{mg}$ of $\mathbf{5}$ ( $0.3 \mathrm{mmol}, 3$ equiv.) in $5 \mathrm{~mL}$ of $\mathrm{MeOH}$, a solution of $37 \mathrm{mg}$ of $\mathrm{LaCl}_{3} \cdot 7 \mathrm{H}_{2} \mathrm{O}(0.1 \mathrm{mmol}, 1$ equiv. $)$ in $\mathrm{MeOH}$ was added. Also a solution of $26 \mathrm{mg}$ of $\mathrm{TiO}(\mathrm{acac})_{2}(0.1 \mathrm{mmol}, 1$ equiv. $)$ and a solution of $41 \mathrm{mg}$ of $\mathrm{K}_{2} \mathrm{CO}_{3}(0.3 \mathrm{mmol}, 3$ equiv. $)$ were added. The mixture was stirred for $72 \mathrm{~h}$. The excess of $\mathrm{K}_{2} \mathrm{CO}_{3}$ was filtered off, and the solvent was removed at $60{ }^{\circ} \mathrm{C}$ in a vacuum. The product was obtained as an orange solid $(100 \mathrm{mg}) .-{ }^{1} \mathrm{H}$ NMR $\left(400 \mathrm{MHz}, \mathrm{CD}_{3} \mathrm{OD}\right): \delta=7.63$ $(\mathrm{s}, 3 \mathrm{H}, \mathrm{CH}=\mathrm{N}), 7.60\left(\mathrm{~d}, J=2.8 \mathrm{~Hz}, 6 \mathrm{H}, \mathrm{CH}_{\mathrm{Tol}}\right), 6.65(\mathrm{~d}$, $\left.J=7.8 \mathrm{~Hz}, 6 \mathrm{H}, \mathrm{CH}_{\mathrm{Tol}}\right), 6.46\left(\mathrm{~m}, 9 \mathrm{H}, \mathrm{CH}_{\mathrm{Cat}}\right), 2.14(\mathrm{~s}, 9 \mathrm{H}$, $\left.\mathrm{CH}_{3}\right)$. $-\mathrm{MS}((+)-\mathrm{ESI}): \mathrm{m} / z(\%)=2236.63(85)\left[\mathrm{L}_{6} \mathrm{La}_{2} \mathrm{Ti}_{2} \mathrm{~K}-\right.$ $2 \mathrm{H}]^{+}, 1123.50(21)\left[\mathrm{L}_{3} \mathrm{LaTiNaH}\right]^{+}$.

\section{Acknowledgements}

Support by the Deutsche Forschungsgemeinschaft and the Fonds der Chemischen Industrie is gratefully acknowledged. Y.L. thanks the Chinese Scholarship Council (CSC) for financial support.
[1] R. W. Saalfrank, H. Maid, A. Scheurer, Angew. Chem. 2008, 120, 8924-8956; Angew. Chem. Int. Ed. 2008, 47, $8794-8824$.

[2] J.-C. G. Bünzli, C. Piguet, Chem. Rev. 2002, 102, $1897-1928$.

[3] C. Piguet, G. Bernardinelli, G. Hopfgartner, Chem. Rev. 1997, 97, 2005-2062.

[4] M. Albrecht, Chem. Rev. 2001, 101, 3457-3498.

[5] M. J. Hannon, L. J. Childs, Supramol. Chem. 2004, 16, $7-22$.

[6] M. Albrecht, Bull. Chem. Soc. Jpn. 2007, 80, $797-$ 808.

[7] J.-M. Lehn, A. Rigault, J. Siegel, J. Harrowfield, B. Chevrier, D. Moras, Proc. Natl. Acad. Sci. U.S.A. 1987, 84, 2565-2569.

[8] V. C. M. Smith, J.-M. Lehn, Chem. Commun. 1996 $2733-2734$.

[9] C. Piguet, G. Hopfgartner, B. Bocquet, O. Schaad, A. F. Williams, J. Am. Chem. Soc. 1994, 116, $9092-9102$.

[10] C. Piguet, G. Hopfgartner, B. Bocquet, O. Schaad, A. F. Williams, J. Am. Chem. Soc. 1994, 116, $9092-9102$.

[11] M. Albrecht, R. Fröhlich, J. Am. Chem. Soc. 1997, 119, $1656-1661$.

[12] F. E. Hahn, M. Offermann, C. Schulze Isfort, T. Pape, R. Fröhlich, Angew. Chem. 2008, 120, 6899-6902; Angew. Chem. Int. Ed. 2008, 47, 6794-6797.

[13] M. Albrecht, O. Osetska, R. Fröhlich, J.-C. G. Bünzli, A. Aebischer, F. Gumy, J. Hamacek, J. Am. Chem. Soc. 2007, 129, $14178-14179$.
[14] M. Albrecht, O. Osetska, J.-C. Bünzli, F. Gumy, R. Fröhlich, Chem. Eur. J. 2009, 15, 8791-8799.

[15] M. Albrecht, Y. Liu, S. S. Zhu, C. A. Schalley, R. Fröhlich, Chem. Commun. 2009, 1195 - 1197.

[16] M. Albrecht, I. Janser, S. Kamptmann, P. Weis, B. Wibbeling, R. Fröhlich, Dalton Trans. 2004, 37-43

[17] SPARTAN O8, Wavefunction Inc., Irvine, CA (USA) 2009.

[18] R. Hooft, Collect, Nonius KappaCCD Data Collection Software, Nonius BV, Delft (The Netherlands) 1998.

[19] DenZo-SMN, Z. Otwinowski, W. Minor, in Methods in Enzymology, Vol. 276, Macromolecular Crystallography, Part A (Eds.: C. W. Carter, Jr., R. M. Sweet), Academic Press, New York, 1997, pp. 307-326.

[20] R. H. Blessing, Acta Crystallogr. 1995, A51, 33-37.

[21] R.H. Blessing, J. Appl. Crystallogr. 1997, 30, $421-$ 426.

[22] Denzo, Z. Otwinowski, D. Borek, W. Majewski, W. Minor, Acta Crystallogr. 2003, A59, 228-234.

[23] G. M. Sheldrick, SHELXS-97, Program for the Solution of Crystal Structures, University of Göttingen, Göttingen (Germany) 1997. See also: G. M. Sheldrick, Acta Crystallogr. 1990, A46, $467-473$.

[24] G. M. Sheldrick, SHELXL-97, Program for the Refinement of Crystal Structures, University of Göttingen, Göttingen (Germany) 1997. See also: G. M. Sheldrick, Acta Crystallogr. 2008, A64, 112 - 122. 